\title{
Between celebrity and glory? Textual after-image in late eighteenth- century France
}

Jessica Goodman, St Catherine's College, Oxford

\begin{abstract}
:
Eighteenth-century France had a particular interest in identifying and celebrating its 'great men', the model individuals through whom it defined its national identity. Across the century, authors, statesmen, scientists and artists were celebrated by the state, in a cult of glory that culminated in the creation of the secular temple of the Panthéon in 1791. Yet the eighteenth century is also acknowledged as the starting point of a very different sort of recognition: the widespread curiosity in a public figure's private life that lies at the heart of modern celebrity culture. The relationship between these two is complex, and is not yet well understood.
\end{abstract}

Rousseau and Voltaire incarnated these two burgeoning forms of fame. Undisputed celebrities in their lifetimes, they were also early occupants of the Panthéon, surviving the political turmoil that saw revolutionary politicians ceremonially buried and subsequently ejected from the monument with shocking speed. This article examines the literary discourse that surrounded their deaths in 1778 and their later inclusion in the Panthéon, analysing the use that was made of their textual remains and considering how far their glorious posthumous status related to their public image in life. Using these brief case studies, I suggest that authors occupy a privileged place in the conversion of lifetime celebrity into enduring posthumous fame, not only - as has traditionally been argued - thanks to the durability of the text, but also because of its flexibility and a created intimacy that mimics the process by which literary celebrity is created in life.

\section{Keywords:}

literary celebrity, Voltaire, Rousseau, posterity, glory 


\section{Between celebrity and glory? Textual after-image in late eighteenth- century France}

Jessica Goodman, St Catherine's College, Oxford

The language of posterity pervades discourses on reading and writing across time. From Horace's claim that as a poet, 'I shall not wholly die' (2004, p. 216-217) to Derrida's spectral books (1993, p. 32), writing is frequently conceived of as a durable form of communication with the future, which treads a fine line between absence and presence (Goulbourne 2013). Questions of presence and absence also play an important role in modern discussions of literary celebrity, where a ghost-like figure is presented as substituting the real individual that is the living author. The public constructs a 'fictional character' (Lilti 2008, p. 77): a 'disembodied' version of the author that is separated from both the real individual and his text to become a purely representative 'abstract cultural value', used to support dominant ideological narratives (Braun 2010, p. 81, p. 88). Though ephemeral celebrity and posthumous glory are traditionally set up as polar opposites (Lilti 2014, p. 37), the overlapping vocabulary shared by these two areas suggests they might be closer than this standard reading suggests. It is this nexus of words - presence, absence, authorial identity, authorial image, text and monument - that this article sets out to unpick, though the case studies of two eighteenth-century authors who achieved celebrity, literary fame, and posthumous glory.

The text as lasting testament is a longstanding commonplace among writers seeking to ensure their own fame. It is a frequent refrain of Diderot's celebrated correspondence with Falconet on the subject of posterity (1765-1773), which describes 'the new religion of the book, the only truly indestructible monument' (Bonnet 1998, p. 171; Buffat 2008), and it exists today in 
Houellebecq's description of reading as a conversation with an intimate but absent friend (2015, p. 13-14). But Diderot's view of the relationship between the author and his bookmonument goes beyond this commonplace trope. He sees writing as a self-conscious game, in which the author imagines that he is already dead: 'You only speak with any power from the bottom of the tomb. That is where you must place yourself; it is from there that you must address men', he writes in his Essai sur la vie de Sénèque (1969-1973, p. 39). In this model the author, once written, is - in a proto-Barthesian sense ${ }^{1}$ - already absent, already handing over interpretation of his works to an audience. Except in Diderot's version of this authorial death, the writer nonetheless still holds some 'power', for he has become analogous to an authoritative voice from the past. This vision of projection and anticipation has echoes in Marmontel's 1757 Encyclopédie article, 'gloire', which also constructs a complex temporal relationship between imagined fame and the actions carried out to produce it: 'He who transports himself into the future and rejoices in his own memory will work for all the centuries, as if he were immortal [...], for his imagination makes him present to posterity' (vol. 7, p. 716-721). ${ }^{2}$ And authors are particularly well placed to carry out and control such acts of imaginary projection, because their tool is one of communication across time: 'they so often call out to the dead, or address themselves to the men of the future' (Diderot 1875-1877, p. 103). An author's words therefore exist beyond their maker and become separated from him. But the talented writer can put something of himself into his creation, ensuring that in those words, his voice lives on.

Studies of modern literary celebrity also focus on a gap between author and work, but instead of being produced by death, this gap appears once a writer becomes well known. Calweti makes a distinction between literary fame (whose subject is the words produced) and later celebrity (focused on the producer and his life) (1977, p. 164), whilst Cashmore describes a historical shift from achievement-based fame to media-driven renown (2014, p. 21-49). In each of these accounts, the 'celebrity' is produced by but quickly supersedes the

\footnotetext{
${ }^{1}$ Indeed, Barthes himself would later write Roland Barthes par lui-même 'speaking about myself as though I were more or less dead' (Barthes 1977, p.168).

${ }^{2}$ On tenses used to talk about death in early modern France, see Kenny 2015.
} 
'literary', resulting in the paradoxically 'disembodied' author, the pure 'brand' described by Braun (2010, p. 80-83), who is cut off from both his text and his bodily self even as his personal existence becomes a subject of interest, and who is solitary because his real self remains unknown (Lilti 2014, p. 153-219).

These two different moments in an author's trajectory - lifetime literary celebrity, and posthumous literary fame - might seem to form part of an obvious progression: in life a (constructed) version of the author figure takes precedence over the text, which returns as an important remnant, a site for new constructions, once the human subject of curiosity, media interest and biographical criticism is no longer present. But though immediate reactions to the deaths of more recent celebrities are an important part of contemporary celebrity studies (Courbet \& Fourquet-Courbet 2014, Perkins 2014), critical discussions of modern celebrity including literary celebrity - have until recently tended to minimise any talk of the posthumous reputation that forms such a striking contrast to the flighty ephemerality of lifetime renown. Moran suggests that posterity was important to authors supported by patronage, who could hope for no personal fame in life (2000, p. 7), but at the point in his account when the author becomes a viable celebrity in his own right, posterity disappears, as if it were only of interest whilst 'literary celebrity' per se did not yet exist. Lilti even more explicitly states that celebrity and posthumous glory are not steps on same road, for whilst the former is based on interaction with contemporary circles, the latter comes from posterity 'as incarnated by "men of taste" and cultural institutions' (2014, p. 37). In his account, celebrity and glory are parallel, but unrelated tracks. H.J. Jackson's 2015 study is the first to tackle posthumous literary fame explicitly, but though her examination of its cultural construction in eighteenth-century Britain provides invaluable context for what follows, even this analysis emphasises the break between lifetime literary success and lasting fame (p. 84). Yet the similarities in theoretical discussions of posthumous literary reputation and lifetime celebrity suggest that they might be more closely linked than the accounts cited above give them credit for, and, furthermore, that exploring these connections in the context of literary fame might 
prove enlightening about celebrity, posterity, and the status of author and text in relation to both.

Eighteenth-century France is a particularly productive context for this study, for it saw important developments in three different types of fame. The end of patronage meant individual cultural producers were more responsible for their reputation in life than ever before, whilst an increasing secularisation was slowly shifting the focus from heavenly to earthly glory. These changes combined with the development of a mass print media, circulating images and anecdotes of famous individuals, to set the scene for a type of celebrity that is recognisable today (Tillyard 2005, Morgan 2011). Lilti's valuable 2014 monograph identifies four key features of this emerging celebrity. First, and most importantly, curiosity: the interest of the public in the personal life and actions of the famous figure, resulting in a false sense of intimacy (p. 14-15, see also Schnickel 1985, Mole 2007). ${ }^{3}$ Secondly, the existence of the fan: individuals who constitute their identities and social groupings through a common interest in the celebrity (p. 65-73, see also Heyd 2014). Thirdly, the fact that a celebrity has an influence in the present, rather than being an example from the past (p. 58). And finally, its levelling nature: it is applicable to famous individuals in all areas of life, from actors to emperors (p. 14). As a clear forerunner of the modern phenomenon, this eighteenthcentury proto-celebrity is a valuable arena in which to examine the mechanisms by which celebrity functions. And France is an especially pertinent context for comparisons with modern literary fame, for in the period, French occupied the position of global linguistic dominance now held by the English language.

But if the eighteenth century was the birthplace of modern celebrity, it also saw new developments in a very different type of fame. The concept of 'glory' - whose history stretched back to ancient times - found its French expression in the 'cult of great men' (Bonnet 1998). This movement involved the identification and celebration of 'glorious' individuals seen as constituting the heroes of the French past: increasingly not kings and

\footnotetext{
${ }^{3}$ I employ Lilti's terms 'curiosity' and 'fan' in full awareness that they are not contemporary: I believe such anachronisms, when used in consciousness of their limits, can be useful tools in linking similar practices throughout history.
} 
military champions, but figures from other areas of life who could act as exemplars for present citizens. In many ways, this was the opposite of celebrity as set out by Lilti: utility, rather than curiosity, was the driving force, with an interest in the details of an individual's life replaced by a focus on their moral status and their contribution to the collective endeavour of advancing human knowledge.

Where celebrity created personal communities of fans, glory was about community on a national scale. 'Great men' were chosen by official bodies: representatives of the court and institutions like the Académie Française, or, later, the National Assembly, who sought to define through them what it meant to be French; particularly important following the turmoil of the Revolution (Bell 2001). And by definition, the influence of these past greats was not immediate or ephemeral, but long lasting. Indeed, 'glory' was almost universally defined as posthumous; as something that could not be accorded until several years had passed. The Encyclopédie described 'gloire' as a reputation that exists 'where you are not, where you shall never be' (vol. 7, p. 716-721), and posterity is the prime example of this sort of presence in absence. A cult of official commemoration celebrated national heroes with statues, portraits and lavish state funerals (Bonnet 1998, p. 127-132, Glover Lindsay 2012, p. 76-82), ${ }^{4}$ culminating in the Panthéon, which from 1791 brought together these great men in a single site of celebration. And the term 'great men' is used advisedly, for this discourse of glory was almost entirely male, as were the spaces in which it was celebrated: no woman was pantheonised in her own right until $1993 .^{5}$

The final type of fame evolving in the eighteenth century was a purely literary celebrity. Emmanuelle Mortgat-Longuet (2006) has shown how the history of French literature, and the forerunner of the modern canon, was constructed from the sixteenth century onwards. An initial move to distinguish a specifically French corpus was followed by a gradual shift towards an interest in the producers of this corpus, and their glorification

\footnotetext{
${ }^{4}$ On the nineteenth-century cult of statuary, see Garval 2003.

${ }^{5}$ The trajectories of contemporary female celebrities, particularly authors, provide a fascinating counterpoint to the male figures discussed, though there is no space to do this topic justice. One particularly interesting example is Olympe de Gouges: see Brown 2001 and my forthcoming edition of Gouges' Mirabeau aux Champs-Elysées (2017).
} 
through the publication of complete works, collected 'lives' and grand posthumous editions. This early form of literary fame, which created the 'man of letters' as a distinct social category, nevertheless remained strongly linked to political power, binding moral qualities, social status and artistic ability up in a single package. The most successful artists received the personal stamp of approval implied in the Ancien régime system of royal patronage, which made adherence to the correct codes of 'honnêteté' - the social posture of courtly politeness - a pre-requisite for artistic success (Viala 1985, p. 51-84, p. 186-198). The patron acted as guarantee of both personality and talent, and the select few artists recognised in this way formed a courtly elite, whose artistic worth and associated social status were bound up with their character.

As the eighteenth century progressed, these different attributes became separated. The facet relating to social status and political appropriateness survived on a larger scale in the national contributions feted by the official Panthéon, whilst the personal aspect of reputation reappeared in the celebrity that constructed a falsely personal relationship for a community of fans. Literary ability was directly present in neither of these aspects, and thus a third, distinct form of fame evolved, available to authors based purely on the quality of their writing. Diderot's Encyclopédie definition of 'célèbre' ('famous'), 'a reputation acquired through literary talent, [which] has nothing to do with dignity' (vol. 2, p. 800), evacuates any notion of honour or moral utility, making no reference to an interest in the person or his social position. This is not to suggest that literature as a category was reduced to pure aesthetics: the eighteenth-century man of letters could still be writing weighty scientific, religious or political tomes. But aesthetic, stylistic or emotional impact and innovation - the specific tools of a writer's trade - could now alone act as reason to be known and admired. This fame through talent alone is the same 'literary fame' that Calweti defines as a counterweight to an author's ephemeral personal celebrity in his modern examination of the phenomenon. That it 
should have come into being as a discrete value at the same time as celebrity-curiosity is therefore not surprising. ${ }^{6}$

Voltaire and Rousseau are a constant presence in discussions of all three types of eighteenth-century fame. Following the standard model of literary renown, once their writings had achieved widespread admiration, their reputations quickly moved beyond this textual output to make them undisputed celebrities: the subject of gossip, anecdote, image circulation, and more. Their withdrawals from Parisian public life - Rousseau as a misanthropic hermit figure, Voltaire to his exile at Ferney - encouraged the creation of myths around them: numerous literary anecdotes revolve around a visit to one or the other (Mostefai 2003), with physical proximity and personal connection prized above all. This position in the modern celebrity culture of assumed intimacy was only strengthened by their representation in a variety of media for public purchase: the most popular engraving of Voltaire in the period showed him getting dressed (Lilti 2014, p. 30-32).

Following their deaths, both Voltaire and Rousseau were incorporated into the logic of official, glorifying, posthumous fame, as some of the first 'great men' to be interred in the secular temple of the Panthéon. The monument was intended to celebrate predominantly postrevolutionary heroes (Madival \& Laurent 1862, vol. 24, p. 536-537), but the two Ancien régime authors were included by special dispensation, in view of their proto-revolutionary ideas. And if they were unique in their inclusion in the Panthéon, they were even more unique for remaining there. The political heroes of the Revolution were interred and disinterred with alarming speed - Mirabeau, whose death had inspired its creation, was soon discovered to have been secretly collaborating with the king and summarily ejected. His replacement, Marat, was in turn removed just months later. As a result, Voltaire and Rousseau occupied the vast building alone from 1795 to 1806 (Ouzouf 1984, Goodman 2015).

\footnotetext{
${ }^{6}$ William Marx (2005) sees this moment as the apogee of literary fame: figures like Voltaire retained the socio-political status of their forerunners, whilst also being admired for their literary value. The status of author was therefore at its most prestigious, prior to a gradual disintegration towards - it is implied - the sort of modern literary fame that focuses on personality.
} 
The trajectories of these two authors - the turbulent period for public image and cultural memory in which they lived, their literary and personal celebrity in life, their successful transition between this and an altogether different sort of lasting fame in death, and the lines that blurred these three types of fame throughout - make them ideal case studies for considering the relationship between lifetime celebrity and posthumous fame. A full consideration of their self-fashioning, their celebrity and their posterity would fill several volumes. ${ }^{7}$ But it is not my aim here to add to the vast existing literature on their individual reputations. Rather, I use a small sample of the posthumous literary production they inspired - in particular two forms that engage directly with questions of presence and absence - to examine what elements of an author are carried forward when he is no longer present, and what this formation of a posthumous image might tell us about the construction of modern literary celebrity.

The first posthumous literary production inspired by Voltaire and Rousseau was a series of 'éloges' - the speeches of praise for the illustrious dead that frequently formed the topic of Académie Française oratory competitions (Thomas 1819). In the immediate aftermath of their deaths, the public naturally turned to Voltaire and Rousseau's writings as substitutes for and remnants of their now absent producers. When this is combined with the contemporary focus on literary fame as related to literary value, it is unsurprising that in these éloges, both writers are discussed predominantly in terms of their contribution to literary development. Their personal foibles and their political ideas are all given due consideration: Palissot mentions Voltaire's 'innumerable acts of charity' (1778a, p. 41) and Rousseau's 'purely personal singularity' (1778b, p. 15), whilst La Harpe notes 'the marked influence [Voltaire] had on his century, which will continue into posterity' $(1780$, p. 2). But by far the most important feature

\footnotetext{
${ }^{7}$ Lilti 2008, Lilti 2014, p. 153-219 and Arnold 2014 are good starting points on Rousseau, with bibliographies that point to the vast corpus regarding his posterity; for studies on Voltaire and selffashioning see, among others, Lilti 2014, p. 25-37 and Cronk 2011.
} 
is the style, versatility and innovation of their writing, as indicative of both their genius and their advancement of the artistic heritage of France. Indeed, the works through which this contribution is accomplished are often analysed in great detail. La Harpe's fifty-one pages on Voltaire's literary genius and innovation in every domain are balanced by just twenty on the content of this writing, which still predominantly focus on his persuasive style and his status as a role model for future writers (1780). Meude-Monpas, who considers each of Rousseau's works in turn, describes his Émile as 'the development of all the faculties of this great writer $[\ldots]$ the assembly of all possible demonstrations of eloquence and human knowledge' (1790, p. 13). And the éloge of Voltaire written by Frederick of Russia (1778) also takes a text-bytext approach, stating that an author's writings, 'the single instrument of his fortune and his reputation' (p. 7), take on a particularly important status after his death.

This explicit focus on literary, textual value would be modified in later representations. A series of works produced around the creation of the Panthéon (1791) indicate how Rousseau and Voltaire existed in the public imagination by the time they were designated for inclusion in the monument. These texts belong to the genre of the 'dialogue of the dead': a classical form, revived in seventeenth-century France, which to some extent reflects the Panthéon in bringing together famous souls in conversation in the afterlife. It is traditionally read as a critical, satirical genre, but though the early modern French examples often did fulfil this purpose (Egilsrud 1934, Pujol 2005, p. 231-247, Andries 2013, p. 131146), the explosion of dialogues produced around the creation of the Panthéon indicates how in this period they also became a form of commemoration; another expression of the cult of great men (Goodman 2015).

The dialogues, some of which were written for performance, explicitly tread that same line between presence and absence that links contemporary literary celebrity with historical literary posterity. Emily Shortslef describes Shakespeare's history plays, which also revive the famous dead before an audience, as 'embodied epitaphs', understanding 'epitaphic' as designating a text with an uncanny presence-absence (2010, p. 11). The epitaph plays into the desire for contact and community creation that is so key to notions of modern celebrity: it 
is the last word of the dead, often inviting the passer-by towards some action (to remember, to pray) and thereby creating continuity between past and present; a version of Diderot's 'speaking to the future'. In these dialogues of the dead, however, there is no last word, for the fiction of encounters in the afterlife allows the protagonists to go on speaking. This is their key generic difference from both the éloges and from traditional history plays: rather than resuscitating the hero at his greatest moment, they allow him to exist in the contemporary world, and thus to react to new events - in this case the Revolution. These texts therefore exist on a boundary where the author-subject is neither alive nor completely dead.

The remainder of this article considers three theatrical dialogues of the dead in which both Rousseau and Voltaire appear: Aude's Le Journaliste des ombres, performed in July 1790 at the Comédie-Française (1790), and two plays written to commemorate Mirabeau: Mirabeau aux Champs-Elysées (1991) by Olympe de Gouges, and L'Ombre de Mirabeau (1791) by Dejaure, performed at the Comédie-Italienne in April and May 1791 respectively. In these plays, it is striking how the emphasis has changed with respect to the éloges written a decade or so earlier. Though a vocabulary of distinction and explicit references to the Panthéon and national glory indicate that Voltaire and Rousseau are still comfortably recognised as belonging to the category 'national greats', the plays diverge from the éloges in the precise features that are selected as praiseworthy.

The literary value - the stylistic and generic innovation - that was the main focus of the earlier texts is far less prominent here: rather than describing the authors' great contribution to literature for its own sake, the focus is on the actions effected by their writings. An example of this shift in emphasis is a passage from Dejaure's play, in which the character 'Mirabeau' explicitly praises the writing of both men. The actions, instruction and enlightenment produced by their work (in bold) are paired with and privileged over its aesthetic value (in italics):

Your sublime writings [Voltaire] have illuminated the world.

And produced for its glory a great change That, foreseen for some time, was accomplished in a moment $[\ldots]$ Often your illumination came in the form of an amusing tale; [...] In your work the art of instruction was born from the art of pleasure; 
Artful dispenser of ridicule,

Your skilful pen lent a mocking air

To severe reason. And you [...] oh sublime Rousseau!

Truth guided your eloquent paintbrush.

Courageous spirits and ardent souls

Found in your writings useful lessons. (1791, p. 13)

Whilst utility was also present in the éloges, it was often covered in passing. Here it takes centre stage.

Moreover, in all three plays, both men are presented as explicitly aiming to create revolution through their writings. In the Gouges text, Rousseau assures Voltaire that he 'provided the basis of everything great and useful that has happened in France' (1991, p. 106). In Aude's play, the two men credit one another with being the inspiration for the Declaration of the Rights of Man: 'Of all the stones that the agreement sets out to keep in place, Jean-Jacques laid the very first' (1790, p. 24-25), whilst Voltaire 'fought the tyrants of the earth, $[\ldots]$ unmasked imposters [and] [...] rescued the unfortunate' (1790, p. 25). Finally, Dejaure has Rousseau suggest his writings prepared the revolution, and Voltaire claim to have predicted its arrival (1791, p. 11). Clearly the authors of these plays seek to praise the new regime by giving it roots in the thinking of these great men: hindsight allows them to present the progression from Rousseau's political theory to revolution as inevitable. But in doing so they shift the focus from these men as writers, to these men as political thinkers, and even proto-revolutionaries.

Though these plays, performed on the public stage, were aimed at a more diverse audience than the academic éloges, the change in emphasis is not just a property of genre, but echoes broader opinions, as represented by the official discourse of pantheonisation. In May 1791, Regnaud told the National Assembly:

It is not to [Voltaire's] talent alone that I pay homage; it is not to the most distinguished mind of his century [...] I rather [...] claim [this honour] for the philosopher who was among the first to dare to talk to the people of their rights, of their power, at the heart of a corrupt court. (Madival \& Laurent 1862, vol. 26, p. 610)

The shift from the specific qualities of the writing itself to the beneficial effects of that writing as a body of work is also visible in a statement by the son of Voltaire's one-time enemy Fréron, who now considered him not 'the irascible writer who vomited slander and 
calumny, but the great man and benefactor of humanity' (L'Orateur du peuple, cited in Bonnet 1998, p. 306). Rousseau, meanwhile, was the subject of the Académie's éloge competition for the revolutionary year, and stones from the fallen Bastille were engraved with his effigy (Bonnet 1998, p. 306), linking him to the very fabric of French history. The Revolution had created a pressing need for new great men to represent the free French nation. Voltaire and Rousseau - who had a weighty historical and literary status, but could also plausibly be constructed as having propagated revolutionary ideas (Swenson 1999) - were understandably attractive.

Yet even as these two authors were being erected as monumentalised great men, the interest in the individual that had characterised their celebrity status in life remained. The longstanding tradition of biographical portraits of dead greats found its eighteenth-century expression in texts such as d'Alembert's Histoire des membres de l'Académie (1775-1777) and Palissot's Nécrologe (1764-1782), the latter focusing on accounts given by individuals who had known the subject in question. It is hard not to see in these works - and in the accompanying growth of 'man and work' literary criticism across the nineteenth century (Bonnet 1985, p. 260) - the influence of the cult of celebrity-as-curiosity: the desire to create a form of intimacy with a famous individual in life transformed into a search for intimate details in the traces left after death. Bonnet describes the contemporary éloge as aiming to bring the writer and his audiences closer to the deceased great man: it worked best, he states, when it consisted of a series of vivid tableaux, which recreated the proximity of the contemporary 'visit' (1985, p. 261). In actualising this intimate encounter, the theatrical dialogue of the dead is thus a peculiarly personal form of posthumous commemoration. And just as the fans' personal relationship to the celebrity in life could create fan communities, so the collective experience of the theatre - performing the 'nous' that generalised feelings about the deceased great man in the éloges - connects the personal commemoration of a famous individual with the national project to find figures who could represent and be identified with by the whole French nation. Montesquieu's statement on glory - 'to do great things, it is not necessary to be such a great genius, or to be above other men: rather, you must be with them' 
(1964, p. 996) - dovetails unexpectedly with Marshall's discussion of celebrity filtered through Max Weber's theories on emotion, in which the celebrity is a unique individual but also representative, and for whom collective affection can promote social stability (1997, p. 52-56, cited in Morgan 2011, p. 100). ${ }^{8}$

In the three plays examined here there is a clear sense that Voltaire and Rousseau will be recognised, both physically (Gouges says they should wear appropriate costumes; 1991, p. 90), and by their character traits: this implies a level of personal celebrity that endured even several years after their deaths. Indeed, contemporary reviews suggest that the stories that had been told about these men and their personalities in their lives had crystallised into enduring set-piece images. The resulting caricatures might be comic, as in Gouges' play which 'made the audience laugh a lot' (Cadet de Vaux 1777-1792, 17 April 1791, p. 432), or more respectful and aggrandising, like the Dejaure play that captured 'the lively and sublime genius of the old man of Ferney' and 'that burning sensibility which tormented Rousseau' (Tutot 1784-1793, June 1791, p. 333-337). And the Rousseau figure in Dejaure's play suggests that the sort of personal affection that a well-loved, recognisable character can inspire made its own important contribution to an individual's posthumous life:

Without a doubt a monument erected by the people Is the most beautiful gift that a deceased man can expect, But would that their heart should keep my image alive! (1791, p. 15)

In their intimate depiction of famous individuals reunited with friends and former enemies, the plays seem to combine elements of the domestic drama of Diderot and Beaumarchais (Gaiffe 1971), in which the details of everyday life were revalorised, with the patriotic plays focusing on recent history championed by Mercier (1999, p. 1176-1189).

But in this new version of accessible exemplarity that brings together national glory and intimacy, the key to the successful afterlives of Voltaire and Rousseau remains the

\footnotetext{
${ }^{8}$ Burke notes that when Barthes returns to a form of authorial biography following his 'death of the author', it is not with grand narratives but with a series of almost personal vignettes, reducing the author from the nineteenth-century god-figure to something resembling mortality (1998, p. 39). But even in the eighteenth century the growth of the novel and the development of autobiography (notably Rousseau's Confessions) gave the audience's relationship to books and their authors an increasingly personal dimension.
} 
writing on which both images were based. The reason these figures can so effectively be resuscitated and made to go on half-living in these texts is precisely their status as authors, which lies at the basis of both their reconfigured political worth, and their personal presence. In the age-old tradition of textual ghosts, Voltaire and Rousseau are already creations made of words, who speak to and influence the future in (a version of) their own voice. The nonauthorial characters evoked by Gouges, Aude and Dejaure are complete fabrications, at the very best second-hand versions of those they represent. But the textual selves of Voltaire and Rousseau are always inevitably present in these reinvented versions of the two great men, as their new authors, intentionally or otherwise, use their words.

Gouges' play is one of most fertile examples of Voltaire's textual presence, from the subtle to the explicit. At one point, in a nod to Candide and Pangloss's best of all possible worlds, 'Voltaire' affirms that 'everything is currently, I'll wager, in the best possible order' (1991, p. 107), whilst discussing religion, he is made to quote himself when he states that 'if God did not exist, we would have to invent him' (1991, p.118). Later, in an even more complex half-citation, Voltaire introduces Louis XIV onstage by quoting verses he wrote in his Siècle de Louis XIV (1991, p. 115); verses which were themselves a quotation - albeit modified - from Racine. The pervasive presence of these texts should not just point to the trope of the written word as enduring: the 'immortal writings' that are discussed by the authors in Gouges' play (1991, p. 106), or the book-monument described by Diderot. For these are not official, monumental publications: complete works, edited editions, or memorial performances. Instead they are snippets, re-appropriations, ventriloquisings in a new context. This less formal textual presence brings together their literary powers (providing memorable quotations) and their glorious political ideas (easily appropriated by the Revolution) with a personal element linked to the intimacy of proto-celebrity. The original authors are still, somehow, present to the future as real individuals, who spoke, and (having, perhaps, already imagined themselves dead) can continue to speak, in a voice that provides a link between the celebrity in whom the public was interested in life, and the image of them left after death. 
In these two men, national glory and utility, personal qualities and literary value, are all connected by the echoing of their own words across the years. And the key feature that allows them to be equally valuable as celebrities in life, as great authors both in the final years of the Ancien régime and in the modern day, and as great men post-revolution, is the flexibility of this vector through which their fame is conveyed, which can be reinterpreted and reappropriated by later writers. Braudy states that the glorious figures of the past can be idealised precisely because they are safely dead (1986, p. 6). But just as valuable - if not more so - is a model who can be continually adapted to suit new contexts, to speak (literally) to new audiences on their terms (Braudy 1986, p. 15). Indeed, the images created by posterity are purely for the benefit of others: not just constructed by the audience, but oriented towards them. In his advice to writers of éloges, Thomas suggests:

Do not forget that your aim is to be useful. [...] What use are your vain praises to the dead? It is to the living that you must speak; $[\ldots]$ present to them endless images of heroes and useful men, and let this idea stir them to action (1819, vol. 2, p. 227).

Jackson's examination of the posterity of Rousseau and Voltaire's British contemporaries concludes that the most successful afterlives belong to those whose works lent themselves to adoption by a variety of new constituencies across time $(2015$, p. $7-8)$. This is a very different definition of literary greatness to the gradual establishment of consensus implied by inclusion in a single, unchanging canon. But the reconfiguration of Voltaire and Rousseau to participate in revolutionary discourse is - just as much as the earlier focus on their literary value, and their later incorporation into the French canon - an example of such contextually motivated recuperation. They become 'myths' in the Barthesian sense: figures (re)produced over time as the originals and their textual production are consumed by new audiences (Barthes 2002, p. 1023).

Rousseau - who had initially seen in the text a direct and authentic mode of communication - eventually came to distrust the readers of the future, whom he feared would 
see him only 'as they wished to see him' (1959-1995, p. 763). But it is precisely this ability of words to be re-appropriated and reinterpreted that allows his memory, and that of Voltaire, to survive and be renewed where that of political heroes - whose glory consisted in single actions that could never again be experienced at first hand - failed. Indeed, it is through these multiple (re)constructions, which transmit the voice of the disembodied dead author through time, that the author continues not only to exist, but also to influence, even to participate in on-going conversations; escaping from the bounds of specific material outputs and institutions to live again in new worlds. ${ }^{9} \mathrm{We}$ are squarely, here, within the realm of Terence Cave's influential notion of 'afterlives', a term he has applied to uses and reuses of texts (in particular those of Montaigne) and fictional characters (especially Goethe's character Mignon) over time. The latter study is particularly illuminating. Mignon's afterlives are multiple and diverse, but each carries some elements of the others within it: each new 'Mignon' focuses on very specific elements of the original, but nonetheless evokes all the qualities of the whole (2011, p. 6, p.23). Moreover, it is the gaps in the narrative - like the absence created by the author's death - that allows subsequent readers to construct these new versions, both retaining and reinvigorating the voice of the original (2011, p. 9-11, Holland \& Scholar 2009, p. 5).

That these points, predicated on a fictional individual, a textual creation, ring so strikingly true for the continually reconstituted image of the author, underlines how this image is itself a fiction, formed of the author's own text as it is reshaped over and over in new contexts. And if the author's existence as semi-fiction born of flexible discourse is key to a successful afterlife, then we have to rethink the status of the 'disembodied' author of modern literary celebrity; the brand apparently separated from both text and biological referent (Braun 2010, p.82), which nonetheless shares these qualities of textually-rooted fabrication with the authorial image in posterity. The secondary supports for this fabrication might shift from newspaper articles and Twitter accounts in life to literary criticism and biography after death,

${ }^{9}$ Cf. Braudy's concept of 'intrinsic charisma' (1986, p. 380-382): an ahistorical cultural authority detached from a specific political context, which can move followers to action even after the individual's death. 
but even in our multi-medial world, the process by which the image of an author is constructed by the individual reader remains broadly the same. Put simply, if we credit the text with the power to carry its author into posterity, then it must be accorded that same power in life; a power that modern discourse on literary celebrity, in focusing on how the text is superseded by the fabricated version of the individual, has tended to dismiss.

This is not, then, a discussion about the extent to which it is possible - or desirable to access the 'real person' of the author when reading his work. Instead, this is about the personal experience of the reader and his relationship to or identification with a figure called 'the author'. A figure who, more than any other type of famous individual transformed into fiction by his public, can make some sort of contribution to his own image, for he wields a tool that allows him consciously to deal with and shape his own fame (Moran 2000, p. 70). Authors have traditionally been entrusted with ensuring the glory of others: the Encyclopédie is explicit about how 'men of action' require men of letters to transmit their great deeds to the future (vol. 7, p. 716-721). Their vehicle for conveying that glory is language, in all its flexibility and instability, and that same vehicle provides its creator with both a contemporary and a posthumous presence. In his 2015 examination of ways to model authorial influence, Andrew Piper posits that an author's impact over time might be tracked by mapping the use of his distinctive vocabulary, because 'language carries us' (p. 196). This model, in reducing an author to a collection of words, seems controversial. But it is the logical extreme of the argument that I have set out over the preceding pages: that the author's words, his discourse, his voice, as initially contained within his text, are both the starting point and the most pervasive remnant for readings, re-readings and reconstructions, that take place both in his lifetime and after his death. Moreover, this phantom body of work not only outlives the biological body and the celebrity image of its creator, and extends beyond specific versions of the written text, but also carries elements of all of them within it. This is why the author 'does not entirely die $[\ldots]$ like other men' (Bollioud-Mermet 1765, p. 52-53).

Writing is therefore doubly powerful. First, and most obviously, it is a form of preglory: it can project posthumous glory before death, through an expression of the desire to be 
remembered and a mastery of the vehicle by which this remembrance will be ensured. But it might also be described as post-celebrity, for the language of conversation and presence in which the author's relationship to his reader is so frequently described (Goulbourne 2013) is closely related to the false presence, the assumed intimacy of broader celebrity-curiosity. And if celebrity describes the mediatised and mediated relationships formed between famous individuals and the world, it is little surprise that literary fame - and in particular posthumous literary fame - should function according to similar mechanisms, for writers have been negotiating such mediated relationships for centuries. Indeed, the communities of readers who pore over a text, read and re-read, debate its meaning and enter into conversations with and about it, are not that dissimilar from the communities of fans who bond over their mutual interest in - and faux intimacy with - a living celebrity, whose ghostly presence can continue to bind them even once it has departed (Courbet \& Fourquet-Courbet 2014). Celebrity, posterity and the written word can therefore act as productive models for one another in the broadest sense.

Thus despite the ostensibly political motivation for their inclusion in the Parisian monument, Voltaire and Rousseau were pantheonised not as glorious celebrities or protorevolutionaries, but as authors: their consecration as great men at this particular moment was just one symptom of how the endurance of their works facilitated their entry into a series of communities over time. The version of them that was pantheonised might have been finite, and adapted to a very precise context, but so was every version of them constructed by readers throughout their lifetimes and after their deaths, whilst the words from which each version was constructed, with which each subsequent audience entered into conversation, remained untouched, ready for the next generation to revisit. The dialogues of the dead explicitly stage this process of conversation and appropriation, in a context of personal encounter that reveals how an author's words - though in many senses the most minimal definition of his function - are not only lasting, but also carry within them the building blocks for resurrecting multiple new versions of that individual. An author's voice, and the character embodied by that voice, can thus both survive their side-lining by a celebrity culture focused 
on the famous individual in life, and continue to resonate in the future. Literary celebrity becomes, in its most essential form, no more or less than an on-going conversation that writing individuals can have with and about the world.

* Thanks to Antoine Lilti, Alain Viala, Ruth Scobie, Rebecca Braun and two anonymous readers for their insightful comments on drafts of this article, to other members of the 'Authors and the World' project for discussion and suggestions at our various meetings, and to Clare College, Cambridge and St Catherine's College, Oxford for research funding. All translations from French are my own unless otherwise noted.

\section{References}

Alembert, J. le R. d', 1775-1777. Histoire des membres de l'Académie morts depuis 1700 jusqu'en 1771, pour servir de suite aux Éloges imprimés et lus dans les séances publiques de cette compagnie. 6 vols. Paris: Moutard.

Andries, L., 2013. Querelles et dialogues des morts au XVIIIe siècle. Littératures Classiques, $81(2), 131-146$.

Arnold, W., 2014. Rousseau and Reformulating Celebrity. The Eighteenth Century, 55 (1), 39-55.

Aude, J., 1790. Le Journaliste des ombres ou Momus aux Champs Élysées. Paris: Gueffier.

Barthes, R., 1977. Roland Barthes by Roland Barthes [1975]. Trans. by Richard Howard. London: Macmillan.

Barthes, R., 2002. 'Phénomène ou mythe?' In: Barthes, Euvres complètes. Ed. É. Marty. Paris: Seuil, 5, 1022-1023.

Bell, D., 2001. The Cult of the Nation in France. Inventing Nationalism, 1680-1800. Cambridge, MA: Harvard University Press.

Bollioud-Mermet, L., 1765. Essai sur la lecture. Lyon: Duplain.

Bonnet, J.-C., 1985. Le Fantasme de l'écrivain. Poétique, 63, 259-277.

Bonnet, J.-C., 1998. Naissance du Panthéon. Paris: Fayard.

Braudy, L., 1986. The Frenzy of Renown: Fame and its History. Oxford: OUP.

Braun, R., 2010. Cultural Impact and the Power of Myth in Popular Public Constructions of Authorship. In: R. Braun and L. Marven, eds. Cultural Impact in the German Context: Studies in Transmission, Reception and Influence. Rochester, NY: Camden House, 78-96. 
Brown, G. S., 2001. The Self-Fashionings of Olympe de Gouges, 1784-1789. Eighteenth Century Studies, 34.3, 383-401.

Buffat, M., 2008. Diderot, Falconet et l'amour de la postérité. Recherches sur Diderot et sur l'Encyclopédie, 43, 9-20.

Burke, S. 1998. The Death and Return of the Author. Criticism and Subjectivity in Barthes, Foucault and Derrida, $2^{\text {nd }}$ ed. Edinburgh: Edinburgh University Press.

Cadet de Vaux, A.-A. et al., 1777-1792. Journal de Paris. Paris: Quellau.

Calweti, J., 1977. The Writer as a Celebrity: Some Aspects of American Literature as Popular Culture. Studies in American Fiction, 5 (1), 161-174.

Cashmore, E., 2014. Celebrity Culture. 2nd ed. London: Routledge.

Cave, T., 2007. Montaigne. London: Granta.

Cave, T., 2011. Mignon's Afterlives: Crossing Cultures from Goethe to the Twenty-First Century. Oxford: OUP.

Courbet, D. \& Fourquet-Courbet, M.-P., 2014. When a celebrity dies ... Social identity, uses of social media, and the mourning process among fans: the case of Michael Jackson. Celebrity Studies, 5 (3), 275-290.

Cronk, N., 2011. Voltaire and the posture of anonymity. Modern Language Notes, 126 (4), 768-784.

Dejaure, J.-C., 1791. L'Ombre de Mirabeau. Paris: Cailleau.

Derrida, J., 1993. Spectres de Marx. Paris: Galilée.

Diderot, D., 1969-1973. Essai sur la vie de Sénèque le philosophe, sur ses écrits et sur les règnes de Claude et de Néron. In: Diderot, Euvres complètes. Ed. R. Lewinter. 12 vols. Paris, Club Français du Livre, 13, 279-630.

Diderot, D., 1875-1877. Lettres à Falconet. In: Diderot, CEuvres complètes. Ed. J. Assézat \& M. Tourneux. 20 vols. Paris, Garnier, 18, 79-346.

Egilsrud, J., 1934. Le 'Dialogue des morts' dans les littératures française, allemande et anglaise (1644-1789). Paris: Éditions Véga.

Encyclopédie, ou dictionnaire raisonné des sciences, des arts et des metiers. 1754-1772. 28 vols. Geneva: Briasson.

Frederick II, King of Prussia, 1778. Éloge de Voltaire. Berlin: n.p..

Gaiffe, F., 1971. Le Drame en France au XVIIIe siècle. 2nd ed. Paris: Colin.

Garval, M., 2003. 'A Dream of Stone': Fame, Vision, and the Monument in NineteenthCentury French Literary Culture. College Literature, 30 (2), 82-119.

Glover Lindsay, S., 2012. Funerary Arts and Tomb Cult: Living with the Dead in France, 1750-1870. Farnham: Ashgate.

Goodman, J., 2015. 'Le Néant de ce qu'on appelle gloire': Post-Revolutionary Cultural Memory and the Dialogue des Morts. Romance Studies, 33 (3-4), 179-191. 
Goodman, J., ed., 2017. Mirabeau aux Champs-Elysées and other texts. London: MHRA.

Gouges, O. de, 1991. Mirabeau aux Champs-Élysées [1791]. In: Gouges, Théâtre Politique. Ed. G. Thiele-Knobloch. Paris: Côté-femmes, 89-130.

Goulbourne, R., 2013. Conversations with the Dead in Early Modern France. Modern Language Review, 108, 90-108.

Grimm, Diderot et. al., 1877-1882. Correspondance littéraire [1747-1793]. 16 vols. Paris: Garnier Frères.

Heyd, U., 2014. Fifteen Lines of Fame: Theatrical Representations of Eighteenth-Century Celebrity and the Press. In: I. Baird, ed. Social Networks in the Long Eighteenth Century: Clubs, Literary Salons, Textual Coteries. Newcastle upon Tyne, England: Cambridge Scholars, 99-120.

Holland, A. \& Scholar, R., eds, 2009. Pre-Histories and Afterlives: Studies in Critical Method. Oxford: Legenda.

Horace. 2004. Odes and Epodes. Trans. N. Rudd. Loeb Classical Library. Cambridge, MA: Harvard University Press.

Houellebecq, M., 2015. Soumission. Paris, Flammarion.

Jackson, H.J., 2015. Those Who Write For Immortality: Romantic Reputations and the Dream of Lasting Fame. New Haven: Yale University Press.

Kenny, N., 2015. Death and Tenses: Posthumous Presence in Early Modern France. Oxford: OUP.

La Harpe, J.-F. de, 1780. Éloge de Voltaire. Paris: Pissot.

Lilti, A., 2008. The Writing of Paranoia: Jean-Jacques Rousseau and the Paradoxes of Celebrity. Représentations, 103 (1), 53-83.

Lilti, A., 2014. Figures publiques. L'invention de la célébrité 1750-1850. Paris, Fayard.

Madival, J. \& Laurent, E. et al., eds, 1862-. Archives parlementaires de 1789 à 1860: recueil complet des débats législatifs \& politiques des Chambres françaises. Paris: Librairie administrative de P. Dupont. Available from: http://frda.stanford.edu/fr/ap $>$ [Accessed 18 August 2015].

Marx, W., 2005, L'Adieu à la littérature. Histoire d'une dévalorisation XVIIIe-XXe siècle. Paris: Minuit.

Mercier, L., 1999. Mon bonnet de nuit, suivi de Du théâtre [1773]. Ed. J.-C. Bonnet. Paris: Mercure de France.

Mole, T., 2007. Byron's Romantic Celebrity: Industrial Culture and the Hermeneutic of Intimacy. Basingstoke: Palgrave Macmillan.

Montesquieu, 1964. Mes pensées. In: Euvres completes. Ed. Georges Vedel \& Daniel Oster. Paris: Seuil, 853-1082.

Moran, J., 2000. Star Authors: Literary Celebrity in America. London: Pluto. 
Morgan, S., 2011. Celebrity: academic 'pseudo-event' or a useful concept for historians? Celebrity, Cultural and Social History: The Journal of the Social History Society, 8 (1), $95-$ 114.

Mortgat-Longuet, E., 2006. Clio au Parnasse. Naissance de l' 'histoire littéraire' français aux XVI et XVIIe siècles. Paris: Honoré Champion.

Mostefai, O., 2003. The Author as Celebrity and Outcast: Authorship and Autobiography in Rousseau. In: J.C. O'Neil and O. Mostefai, eds. Approaches to Teaching Rousseau's Confessions and Reveries of the Solitary Walker. New York: Modern Language Association of America. 68-72.

Ozouf, M. 1984. Le Panthéon: l'école normale des morts. In: P. Nora, ed. 1984-1992. Lieux de mémoire. 7 vols. Paris: Gallimard, 1, 140-162.

Palissot, C., 1764-1782. Nécrologe des hommes celebres. 17 vols. Paris: Moreau.

Palissot, C., 1778a. Éloge de Voltaire. Paris: Bastien.

Palissot, C., 1778b, Éloge de M. Rousseau de Genève. Paris: Bastien.

Perkins, C., 2014. The post-mortem star discourse, or, loving Adrienne Shelly. Celebrity Studies, 5 (1-2), 20-31.

Piper, A., 2015. Epilogue: Three Computational Frameworks for the Study of World Authorship. Seminar: A Journal of Germanic Studies, 51 (2), 191-199.

Pujol, S., 2005. Le dialogue d'idées au dix-huitième siècle. Oxford: Voltaire Foundation.

Rousseau, J.-J., 1959-1995. Rousseau Juge de Jean-Jaques. Dialogues. In: Euvres complètes. 5 vols. Ed. B. Gagnebin and M. Raymond. Paris: Bibliothèque de la Pléiade, 1, 657-992.

Schnickel, R., 1985. Intimate Strangers: The Culture of Celebrity in America. New York: Doubleday.

Shortslef, E., 2010. Acting as an Epitaph: performing commemoration in the Shakespearean history play. Critical Survey, 22 (2), 11-25.

Swenson, J., 1999. On Jean-Jacques Rousseau: Considered as One of the First Authors of the French Revolution. Stanford: Stanford University Press.

Thomas, A.-L., 1819. Essai sur les éloges. 2 vols. Toulouse: F. Vieusseux.

Tillyard, S., 2005. Celebrity in 18th-century London. History Today, 55 (6), 20-27.

Tutot, J-J., ed., 1784-1793. Esprit des journaux françois et étrangers par une société de Gensde-Lettres, Paris: Turgot.

Viala, A., 1985. La Naissance de l'écrivain. Paris: Minuit. 